\title{
ORGANIZAÇÃO RETÓRICA DO GÊNERO NOTÍCIA DE POPULARIZAÇÃO DA CIÊNCIA: UM ESTUDO COMPARATIVO ENTRE PORTUGUÊS E INGLÊS*
}

\author{
Désirée Motta-Roth** \\ Cristina dos Santos Lovato**
}

\begin{abstract}
Resumo: O objetivo deste estudo é comparar a organização retórica de 30 notícias de popularização da ciência, publicadas em português e em inglês, nos sites Ciência Hoje On-line e BBC Online. De modo geral, encontramos a indicação dos resultados gerais no lide, seguida da apresentação da pesquisa por detalhamentos dos resultados, descrição dos procedimentos experimentais, com a explicação dos resultados e a conclusão da pesquisa na porção final do texto. Verificamos certas características, tais como o lide que sintetiza os resultados da pesquisa, a apresentação das credenciais dos pesquisadores como recurso de autoridade, a explicação sucinta da metodologia e a alusão ao caráter social e local da pesquisa em relação a uma determinada comunidade. Notamos a recorrência da explicação de conceitos e da avaliação da pesquisa por diferentes segmentos da sociedade. Este artigo discute e ilustra cada uma dessas características e propõe uma representação esquemática do gênero notícia de popularização da ciência.

Palavras-chave: análise crítica de gênero; organização retórica; notícia de popularização da ciência.
\end{abstract}

\footnotetext{
* O presente trabalho foi desenvolvido dentro do Projeto de Produtividade em Pesquisa/CNPq ${ }^{\circ}$ 301962/2007-3, Análise crítica de gêneros com foco em artigos de popularizaçãa da ciência, no Grupo de Trabalho do LABLER-Laboratório Pesquisa e Ensino de Leitura e Redação da UFSM, sob coordenação da primeira autora. Agradecemos aos pareceristas anônimos e a Patrícia Marcuzzo (PPGL/UFSM) pelas sugestões ao manuscrito.

** Professora da Universidade Federal de Santa Maria, RS, Brasil. Doutora em Letras Inglês (Linguística Aplicada).Email: <dmroth@terra.com.br>.

*** Mestranda no Programa de Pós-Graduação em Letras da Universidade Federal de Santa Maria, RS, Brasil. Bolsista da CAPES. Especialista em Língua Portuguesa. Email: <cristina.lovato@yahoo.com.br>.
} 


\section{INTRODUÇÃO}

O acesso corriqueiro da sociedade à experiência científica é feito por meio de textos de popularização da ciência - textos sobre ciência, produzidos por cientistas, jornalistas e escritores, tendo em mente uma audiência formada por leigos e não por especialistas (MYERS, 1990, p. 145, 2003, p. 265; CERRATO, 2002, p. 1). Um documentário televisivo, veiculado pela televisão aberta, um artigo ou reportagem impressa publicados em um periódico de popularização da ciência como New Scientist ou um vídeo divulgado na Internet, em sites como $<$ http://www.popsci.com/category/tags/video>, exemplificam gêneros que servem à função de popularizar a ciência.

A expansão das competências linguísticas na passagem do letramento da vida diária para o letramento acadêmico-científico se constitui em um desafio pedagógico para a disseminação da informação e da cultura e para a democratização do conhecimento (ANDRADE, 2003, p. 100). ${ }^{1}$ Assim, textos constitutivos do processo de popularização da ciência, além de desempenharem uma função pedagógica ao ensinar princípios científicos (MEDEIROS, 2003, p. 90), consolidam e legitimam a prática de pesquisa, impulsionando o crescimento da comunidade científica (p. 83-4) e subsidiando decisões no âmbito dos organismos que integram o Estado (p. 85).

O interesse por estudos sobre o processo de popularização da ciência (doravante PC) originou-se a partir de preocupações de pesquisadores de várias áreas acerca de temas tais como a relação entre ciência e sociedade, a prática jornalística e os efeitos da mídia e a melhoria do ensino de Línguas para Fins Acadêmicos (MYERS, 2003, p. 265). Textos de PC, publicados em revistas como New Scientist, representam a atividade científica diferentemente daquela encontrada em

\footnotetext{
${ }^{1}$ No âmbito do jornalismo científico e da popularização da ciência, Andrade (2003, p. 95-99) define esses dois tipos de letramento como literacias: conjunto de procedimentos argumentativos, interpretativos e judicativos que nos permitem traduzir signos em objetos, práticas e pensamentos e vice-versa. Nesses termos, a "literacia comum cotidiana" é o processo de codificação e decodificação das informações e signos da vida diária; e "literacia científico-tecnológica" consiste nas competências de escrita e leitura de conteúdos de natureza científica ou tecnológica. Sobre a importância da circulação de textos entre os sistemas educacionais e econômicos, ver também Martin e Rose (2007).
}

MOTTA-ROTH; LOVATO - Organização retórica do gênero notícia de popularização... 
artigos científicos (OLIVEIRA, 2005; OLIVEIRA; PAGANO, 2006; PAGANO, 1998, 2001), visto que aqueles apresentam uma organização retórica e um vocabulário simplificado, sem a densidade técnica dos textos acadêmico-científicos. Embora contrastantes, essas duas práticas colaboram para criar e garantir a autoridade que emana da ciência (MYERS, 1990, p. 142).

Tomando como pano de fundo a vida contemporânea, pautada pelo avanço científico-tecnológico e, ao mesmo tempo, pelas condições menos do que satisfatórias da educação brasileira, partimos do pressuposto de que necessitamos de mais pesquisas que subsidiem o ensino de línguas em termos de descrições e análises dos gêneros que constituem as práticas discursivas contemporâneas. $O$ acesso da população brasileira ao conhecimento das pesquisas atuais, por meio da leitura de textos de PC em português ou em inglês como língua estrangeira torna-se, portanto, um direito e uma necessidade na sala de aula de línguas. O ponto de partida deste trabalho é a crença de que um aluno educado cientificamente, no sentido de já manter contato com a ciência na educação básica, desenvolve competências e habilidades para questionar e se posicionar frente a práticas científicas (MOTTA-ROTH, 2007). Argumentamos que a "notícia de popularização da ciência" se constitui em uma rica fonte de pesquisa, um gênero em que se podem explorar as relações entre linguagem, ciência e sociedade, e que resultados de pesquisa em Análise Crítica de Gêneros podem oferecer subsídios relevantes, tanto para o ensino de línguas (materna ou estrangeira), quanto de ciências acerca do modo como os conceitos e as relações entre ciência e sociedade são construídos discursivamente.

Devido a sua potencialidade educacional, exploramos o gênero notícia de PC, veiculada na Internet em português e inglês, com vistas a elaborar uma representação esquemática dos movimentos retóricos (SWALES, 1990) nesses textos. Segundo Lage (apud FRANCESCHINI, 2004, p. 149), a linguagem jornalística é transnacional, pois as técnicas de redação servem para jornalistas de diversas culturas. Assim, tanto jornais norte-americanos, quanto brasileiros, por exemplo, apresentariam a mesma tendência de ordenação das informações. A partir disso, verificamos em que medida essa afirmação pode ser observada em nossa análise por meio da comparação entre textos em português e em inglês, entendendo que o gênero notícia de $\mathrm{PC}$ não é um fenômeno 
eminentemente natural, que emerge da "realidade", mas sim um fenômeno culturalmente determinado pelas práticas sociais (CALDASCOULTHARD, 1997).

Tomamos por referência os estudos da Análise de Gênero (SWALES, 1990, 2004, por exemplo) e da Análise Crítica do Discurso (FAIRCLOUGH, 1989, 1992, 2003, por exemplo) para formular uma perspectiva que chamamos de Análise Crítica de Gênero (MOTTAROTH, 2008). Nossa intenção é demonstrar como certos aspectos do processo social de popularizar a ciência, mencionados na seção 2.1, são linguisticamente realizados em textos classificados como exemplares de um mesmo gênero constitutivo de contextos de situação semelhantes.

\section{REFERENCIAL TEÓRICO}

\subsection{Notícias de popularização da ciência}

As pesquisas sobre PC têm apontado novos usos da linguagem e suas implicações para a população de diferentes comunidades. Atualmente entende-se que a PC é um processo mais complexo do que se pensava no passado.

Hilgartner (1990, p. 519) descreve o processo de PC a partir da "visão dominante da ciência", como uma simplificação ou mesmo distorção desta. Para o autor (p. 520-21), essa visão dominante estabelece que o conhecimento verdadeiramente científico é inacessível ao público não-especialista, que entende mal muito do que lê, sendo, portanto, as questões da ciência o território da autoridade, da manutenção da hegemonia dos cientistas frente a qualquer público que não pertença ao universo da pesquisa (p. 524). O processo de PC é visto como uma "tradução de pesquisas científicas para a audiência leiga" (PAUL, 2004, p. 32), simplificando o processo (HILGARTNER, 1990, p. 521).

Em oposição à visão tradicional de "transmissão" do conhecimento, mais recentemente a PC refere-se a um processo de "difusão" do conhecimento científico, "uma ordem discursiva, um terreno de debates e práticas sociais” (MYERS, 2003, p. 65). Há uma gradação do processo em relação a quão popular ou simplificada é a 
reenunciação do texto científico (HILGARTNER, 1990, p. 524-6). Além disso, a inserção do jornalista-autor como mediador da interação entre cientista e público o coloca como o construtor e articulador de um número variado de discursos que ultrapassam os limites do discurso acadêmico (BEACCO et al., 2002, p. 282). Além de "reformular" o conhecimento científico, o jornalista estabelece nichos de debate político ao informar e questionar as implicações das descobertas científicotecnológicas para a sociedade.

A ciência atualmente incorpora o rol das questões de interesse da sociedade; sua inserção "supõe, por sua vez, a aceitação, pela sociedade, do caráter benéfico da atividade científica e de suas aplicações" (ALBAGLI, 1996, p. 396). O crescente interesse da sociedade pode ser explicado por meio do impacto, muitas vezes, negativo dos avanços científico-tecnológicos na sociedade, tais como a degradação do meioambiente, por exemplo. Nesse contexto, a PC passa a ser um processo muito mais complexo do que simples "tradução", se constituindo em um procedimento transformacional de pesquisas científico-tecnológicas orientado a outros objetivos, como educacionais, cívicos e de mobilização popular (ALBAGLI, 1996, p. 397), os quais vão além do repasse de resultados de pesquisas para o público leigo.

Parafraseando Albagli (1996), a orientação educacional visa à ampliação da compreensão do processo científico e de sua lógica pelo público leigo. A orientação cívica visa à informação do público sobre os impactos das pesquisas científico-tecnológicas, principalmente quanto à tomada de decisões que afetam a sociedade como um todo. Por fim, a orientação mobilizadora prevê a possibilidade de participação da sociedade na formulação de políticas públicas para implantações tecnológicas, por exemplo.

Esses novos objetivos demonstram o apelo à participação da sociedade nas atividades científicas por meio da mídia, para promover debates que incluam, além do próprio pesquisador, o cidadão leigo, dando "maior controle social sobre os impactos da ciência e da tecnologia na vida cotidiana" (ALBAGLI, 1996, p. 398). Sugerem, portanto, a participação da sociedade em discussões sobre questões de cunho social, tecnológico e científico para a solução de problemas resultantes de ações passadas, que ainda afetam a sociedade. 
Comumente é a notícia o gênero jornalístico que, junto com a reportagem, tem a função informativa na mídia (LAGE, 2004; FRANCESCHINI, 2004). Segundo Lage (2005, p. 16), a notícia é definida estruturalmente pelo jornalismo moderno como "relato de uma série de fatos a partir do mais importante ou interessante", numa estrutura lógica (2005, p. 60). A notícia é construída de acordo com técnicas jornalísticas específicas que dizem respeito à escolha de vocabulário, à ordenação de informação e ao tratamento das fontes (FRANCESCHINI, 2004, p. 148). Podemos identificar "notícia" como um acontecimento pontual em contraste com a "reportagem", por exemplo, que discorre sobre um tema, apresentando uma interpretação sobre situações ou fatos relacionados a este (LAGE, 2005, p. 61). Apesar de Bonini (no prelo, p. 3) apontar a dificuldade de se delimitar a "notícia" como gênero no contexto brasileiro ${ }^{2}$, o autor (p. 9) parece compartilhar da mesma acepção de "notícia" adotada neste estudo, como o anúncio de um fato ou evento pontual. Van Dijk (apud BONINI, no prelo, p.10) resume os componentes da notícia como: título, lide, fato central, contexto, eventos prévios, consequências/reações, expectativas e avaliação.

A notícia de PC analisada neste trabalho é produzida por jornalistas para um público-alvo não-especialista (conforme a definição de Gomes, 2000, p. 44) da "matéria de divulgação científica" da revista Ciência Hoje). Seu principal propósito é expandir o conhecimento científico para o público leigo, transformando o conhecimento especializado em conhecimento acessível a leitores não-especialistas (CALSAMIGLIA; VAN DIJK, 2004, p. 370), colocando as novas descobertas científicas em debate público (MOREIRA; MOTTAROTH, 2008).

\subsection{Análise Crítica de Gênero}

A Análise de Gêneros formulada por Swales (1990) explora, entre outras coisas, o modo como a informação é organizada no texto em movimentos retóricos e como esses movimentos são sinalizados

\footnotetext{
${ }^{2}$ Conforme aponta Bonini (no prelo, p. 3), a dificuldade de se definir notícia não é exclusiva ao contexto brasileiro, uma vez que os manuais brasileiros de redação jornalística são baseados em manuais norte-americanos, mais especificamente, naquele elaborado por Bond (1954).
}

MOTTA-ROTH; LOVATO - Organização retórica do gênero notícia de popularização... 
linguisticamente, de modo a demonstrar o modo como certos aspectos do processo social de produzir conhecimento são linguisticamente realizados em textos identificados com e constitutivos desse processo, configurando-se como exemplares de um mesmo gênero.

Cada gênero se caracteriza por um encadeamento de movimentos retóricos - unidades de estrutura discursiva com orientação uniforme, características estruturais específicas e funções definidas (NWOGU, 1991, p. 114). Tais segmentos textuais ou blocos discursivos desempenham funções específicas nos textos. A ideia de movimento retórico está associada ao estudo dos padrões retóricos recursivos encontrados em diferentes textos, nos quais diferentes segmentos textuais desempenham diferentes funções comunicativas (MOTTAROTH, 1995, p. 44).

A Análise de Gênero identifica os gêneros como construtos altamente estruturados, identificados por elementos linguísticos convencionais (BHATIA, 2004, p. 23), recorrentemente encontrados em exemplares de uma classe de eventos comunicativos, cujos membros compartilham alguns objetivos comunicativos (SWALES, 1990, p. 58).

Um segundo aporte teórico, a Análise Crítica do Discurso, contribui para o pensamento crítico sobre gêneros, por seu objetivo emancipador ao buscar desvelar os elementos do sistema de relações sociais presentes no discurso (BHATIA, 2004; AL-ALI, 2006) e tentar avaliar os efeitos desses elementos sobre as relações sociais (FAIRCLOUGH, 1989, p. 5). Além disso, a abordagem sociocultural de Mikhail Bakhtin traz para a Análise de Gênero o interesse na intertextualidade e na interdiscursividade dos gêneros, em termos dos modos característicos de os gêneros serem produzidos e mediados pela relação deles com textos anteriores (BERKENKOTTER, 2001, p. 326327).

Ao propor a análise de elementos linguísticos e retóricos do texto (como na Análise de Gênero estrita), em combinação com a análise dos elementos ideológicos do contexto (como a Análise do Discurso Crítica), a Análise Crítica de Gênero ${ }^{3}$ se presta a um exame da linguagem que é, ao mesmo tempo, detalhado, porque localiza e explica os elementos

\footnotetext{
${ }^{3}$ Ver também Motta-Roth (2008).
} 
linguísticos, e problematizador, porque busca desnaturalizar os valores que estão postos.

Ao trazer, para a análise do texto, a preocupação com as práticas sociais, a Análise Crítica de Gênero também esclarece o significado dos textos para a vida individual e grupal e o papel estruturador dos gêneros para a cultura. Ao possibilitar a análise dos valores sociais dos elementos do texto e inscrevê-lo num sistema de atividades (caracterizado pelos objetivos comunicativos do gênero e pelos participantes da interação, por exemplo), a Análise Crítica de Gêneros permite uma percepção mais acurada da relação entre teoria da linguagem e prática social.

\subsection{Organização retórica das notícias de PC conforme Nwogu}

Há quase duas décadas, Nwogu (1991) estudou a organização retórica de textos de PC com base no modelo CARS de Swales (1990). Analisou 15 exemplares de PC ("Versões Jornalísticas" de artigos acadêmicos de pesquisa da área médica, direcionadas ao público leigo), escritos por "jornalistas de popularização da ciência" (1991, p. 112), em três publicações em inglês (as revistas New Scientist e Newsweek e o jornal The Times), sobre temas relacionados às ciências médicas. O pesquisador elaborou uma descrição esquemática de nove movimentos retóricos (Quadro 1, tradução do original em inglês pela primeira autora), cada um realizando um ato de fala.

Embora raramente apareçam na ordem numerada no Quadro 1, especialmente em se tratando dos Movimentos 3 a 7, essa representação esquemática tenta captar a organização retórica comumente encontrada em versões jornalísticas de artigos acadêmicos para o público leigo (artigos que popularizam pesquisas recentes, publicados em jornais e revistas de grande circulação). Pode ser sintetizada como: breve contextualização do problema (Movimento 1), indicação dos principais resultados da pesquisa (2), limitações dos esforços prévios para resolver o problema (3), indicação dos pesquisadores que conduziram o estudo e seus objetivos (4), indicação de resultados obtidos (5), indicação dos métodos usados na coleta de dados (6), descrição dos métodos usados no experimento (7), discussões e explicações de resultados específicos da pesquisa (8), declaração das principais conclusões da pesquisa e suas implicações para a audiência-alvo (9). 
Movimento 1 - Apresentar informação prévia

Fazer referência ao conhecimento estabelecido na área

Fazer referência ao problema de pesquisa

Enfatizar a perspectiva local

Explicar princípios e conceitos

Movimento 2 - Destacar os principais resultados da pesquisa

Fazer referência aos principais resultados

Movimento 3 - Revisar pesquisas relacionadas ao assunto

Fazer referência à pesquisa prévia

Fazer referência às limitações da pesquisa prévia

Movimento 4-Apresentar a pesquisa

Fazer referência aos autores

Fazer referência ao objetivo da pesquisa

Movimento 5 - Indicar observações consistentes

Declarar resultados importantes

Fazer referência a observações específicas

Movimento 6-Descrever os procedimentos da coleta de dados

Fazer referência aos autores

Fazer referência à fonte dos dados

Fazer referência ao tamanho da amostra de dados

Movimento 7 - Descrever os procedimentos experimentais

Relatar principais processos experimentais

Movimento 8 - Explicar resultados da pesquisa

Declarar um resultado específico

Explicar princípios e conceitos

Indicar comentários e perspectivas

Indicar a significação do resultado principal

Contrastar resultados atuais e prévios

Movimento 9-Apontar conclusões da pesquisa

Indicar implicações da pesquisa

Encorajar pesquisas futuras

Enfatizar a perspectiva local

Quadro 1 - Representação esquemática de textos de PC em inglês por

Nwogu (1991, p. 115-116).

Inicialmente, adotamos essa representação esquemática como referência. À medida que desenvolvemos a análise sobre notícias de PC do nosso corpus, verificamos, entretanto, discrepâncias entre a representação esquemática proposta por Nwogu e as nossas análises prévias. Em análises cruzadas realizadas junto ao GT LABLER, 
detectamos a necessidade de uma nova representação esquemática que capturasse as características do atual corpus coletado em publicações em português e inglês, na Internet (como, por exemplo, a indicação da relevância social da pesquisa ou a alternância de vozes nos textos do nosso corpus). A representação esquemática proposta é desenvolvida neste artigo, conforme os procedimentos da pesquisa relatados a seguir.

\section{METODOLOGIA}

\subsection{Procedimentos de identificação dos sites}

Os critérios para a seleção das publicações e do corpus resultaram de uma análise do contexto de publicação realizada a partir da nossa experiência no LABLER em elaborar material didático de leitura instrumental em língua estrangeira e redação em português com textos extraídos de sites informativos e gratuitos. Investigamos o contexto de publicação de diversos sites e a dinâmica de atualização destes por meio de uma amostragem por projeção. Para serem escolhidos, os sites deveriam apresentar ao menos uma seção de notícias dedicadas à PC. As sessões de cada site destinadas às notícias de PC foram monitoradas durante um período de aproximadamente 10 dias para sabermos o número aproximado de notícias publicadas mensalmente e de livre acesso. Optamos por analisar os sites da revista eletrônica Ciência Hoje On-Line (disponível em http://cienciahoje.uol.com.br/) e da BBC On-line (disponível em http://www.bbc.co.uk) por parecerem os mais imediatamente identificáveis com os critérios de coleta do corpus listados abaixo.

\subsection{Procedimentos de coleta do corpus}

Foram coletadas 30 notícias de PC (Tabela 1) de acordo com os seguintes critérios (MOT'TA-ROTH, 2007):

a) público-alvo: escritas para uma audiência leiga ou de nãoespecialistas;

b) mídia: disponíveis on-line, devido à gratuidade e à acessibilidade;

MOTTA-ROTH; LOVATO - Organização retórica do gênero notícia de popularização... 
d) línguas: publicações escritas em língua portuguesa e língua inglesa;

e) período de tempo: publicadas entre 2001 e 2008; e

e) conteúdo: notícias que reportam pesquisas científicas relacionadas aos temas transversais de saúde, meio ambiente e tecnologia, conforme Parâmetros Curriculares Nacionais (BRASIL, 1997a; 1997b; 1997c; 1997d).

O corpus se subdivide em dois subcorpora: 15 notícias em português sobre temas relacionados às ciências médicas (saúde); e 15 notícias em inglês sobre três temas: saúde, meio ambiente e tecnologia, identificados nas quadros 2 e 3, respectivamente, coletados nas seções de Notícias e de News de cada site.

\begin{tabular}{|l|}
\hline CH\#1 http://cienciahoje.uol.com.br/controlPanel/materia/view/3130 \\
\hline CH\#2 http://cienciahoje.uol.com.br/controlPanel/materia/view/3084 \\
\hline CH\#3 http://cienciahoje.uol.com.br/controlPanel/materia/view/61198 \\
\hline CH\#4 http://cienciahoje.uol.com.br/controlPanel/materia/view/3068 \\
\hline CH\#5 http://cienciahoje.uol.com.br/controlPanel/materia/view/2979 \\
\hline CH\#6 http://cienciahoje.uol.com.br/controlPanel/materia/view/2980 \\
\hline CH\#7 http://cienciahoje.uol.com.br/controlPanel/materia/view/3081 \\
\hline CH\#8 http://cienciahoje.uol.com.br/controlPanel/materia/view/112048 \\
\hline CH\#9 http://cienciahoje.uol.com.br/112979 \\
\hline CH\#10 ttp://cienciahoje.uol.com.br/controlPanel/materia/view/109886 \\
\hline CH\#11 http://cienciahoje.uol.com.br/controlPanel/materia/view/3040 \\
\hline CH\#12 http://cienciahoje.uol.com.br/controlPanel/materia/view/3085 \\
\hline CH\#13 http://cienciahoje.uol.com.br/101092 \\
\hline CH\#14 http://cienciahoje.uol.com.br/69361 \\
\hline CH\#15 http://cienciahoje.uol.com.br/127454 \\
\hline
\end{tabular}

Quadro 2 - Numeração e endereço eletrônico das notícias do subcorpus em português. 


\begin{tabular}{|l|}
\hline BBC\#1 http://news.bbc.co.uk/2/hi/health/7324555.stm \\
\hline BBC\#2 http://news.bbc.co.uk/2/hi/health/7287792.stm \\
\hline BBC\#3 http://news.bbc.co.uk/2/hi/science/nature/7324654.stm \\
\hline BBC\#4 http://news.bbc.co.uk/2/hi/science/nature/4046427.stm \\
\hline BBC\#5 http://news.bbc.co.uk/2/hi/health/7319251.stm \\
\hline BBC\#6 http://news.bbc.co.uk/2/hi/health/7443534.stm \\
\hline BBC\#7 http://news.bbc.co.uk/2/hi/health/6977423.stm \\
\hline BBC\#8 http://news.bbc.co.uk/2/hi/health/6483403.stm \\
\hline BBC\#9 http://news.bbc.co.uk/2/hi/health/6655221.stm \\
\hline BBC\#10 http://news.bbc.co.uk/2/hi/health/4632886.stm \\
\hline BBC\#11 http://news.bbc.co.uk/2/hi/health/7445606.stm \\
\hline BBC\#12 http://news.bbc.co.uk/2/hi/health/7075511.stm \\
\hline BBC\#13 http://news.bbc.co.uk/2/hi/health/7208941.stm \\
\hline BBC\#14 http://news.bbc.co.uk/2/hi/uk_news/england/7317745.stm \\
\hline BBC\#15 http://news.bbc.co.uk/2/hi/health/7380567.stm \\
\hline
\end{tabular}

Quadro 3 - Numeração e endereço eletrônico das notícias do subcorpus em inglês.

\subsection{Procedimentos de análise}

Os procedimentos de análise dos dados foram interpretativos e detalhados de modo a analisar elementos linguísticos concernentes aos movimentos retóricos do gênero em questão (BHATIA, 1993, p. 22).

Primeiramente todos os textos foram lidos individualmente por cada pesquisadora e pelos assistentes de pesquisa envolvidos na análise. Todas as orações foram identificadas, as funções retóricas (movimentos e passos) interpretadas e demarcadas manualmente, levando em consideração as descrições feitas por Nwogu $(1990,1991)$ de textos de PC, dos movimentos retóricos que encontrou e do conteúdo de cada trecho do texto. Essa etapa da pesquisa demonstrou que os textos tinham algumas características recorrentes (NASCIMENTO et al., 2007; PRATES et al., 2008; MARCUZZO; MOTTA-ROTH, 2008; MOTTAROTH et al., 2008a; 2008b), mas os movimentos e os expoentes 
linguísticos que possibilitavam a identificação destes ainda precisavam ser delimitados com mais clareza.

Em seguida, desenvolvemos uma análise cruzada em que a primeira autora e uma assistente de pesquisa previamente treinada compararam suas análises particulares do subcorpus em inglês para identificar consensos e divergências sobre a identificação das fronteiras entre os movimentos/passos e o respectivo conteúdo retórico (conforme Anexo 1).

Em terceiro lugar, a primeira autora tentou identificar os expoentes linguísticos que levaram a identificar os vários estágios do texto, como sinalizadores da informação em cada movimento/passo. Voltou às descrições de Nwogu $(1990,1991)$ sobre os expoentes linguísticos que encontrou em inglês e fez uma análise comparativa com os textos em português.

A partir daí, elaborou a atual descrição esquemática do gênero notícia de PC usada neste artigo (mostrada mais adiante no Quadro 4). Por fim, usando essa descrição esquemática, ambas as autoras checaram a análise cruzada dos dois subcorpora. Os resultados da análise dos movimentos e passos nos textos em português e inglês serão relatados na próxima seção. Ressaltamos, porém, que a análise de um corpus mais amplo está atualmente em andamento dentro do projeto de Produtividade em Pesquisa/CNPq Análise crítica de gêneros com foco em artigos de popularização da ciência (MOTTA-ROTH, 2007), portanto a representação esquemática do gênero notícia de PC apresentada aqui não é definitiva, mas demonstra o atual estágio em que a reflexão se encontra.

\section{RESULTADOS}

A análise das notícias de PC em português e inglês indicou uma tendência de organização em seis movimentos retóricos (Quadro 4), com dois elementos recursivos ao longo do texto (A e B). Embora a ordenação dos passos tenha flexibilidade, especialmente em se tratando dos passos 3b e 6c, a numeração no Quadro 4 tenta capturar a 
organização retórica comumente encontrada nas notícias de popularização da ciência analisadas nas duas línguas.

\begin{tabular}{|c|c|}
\hline Movimentos e passos & Elementos recursivos \\
\hline $\begin{array}{l}\text { Move } 1 \text { - LIDE/Conclusão da pesquisa } \\
\text { (previsão) }\end{array}$ & \multirow{6}{*}{$\begin{array}{l}\text { A - Alternância de vozes (para } \\
\text { comentários e opiniões mais positivas } \\
\text { ou negativas) que pode incluir, além da } \\
\text { voz do próprio Jornalista que subjaz a } \\
\text { toda notícia de PC, a voz do ou de } \\
\text { um/a: } \\
\text { a. Cientista/pesquisador (ou } \\
\text { metaforicamente do } \\
\quad \text { estudo); } \\
\text { b. Colega/Técnico/Instituição; } \\
\text { c. Governo; } \\
\text { d. Público. } \\
\text { B - Explicação de princípios e } \\
\text { conceitos (por meio de recursos de } \\
\text { reescritura como aposto, glosa e } \\
\text { metáfora). }\end{array}$} \\
\hline 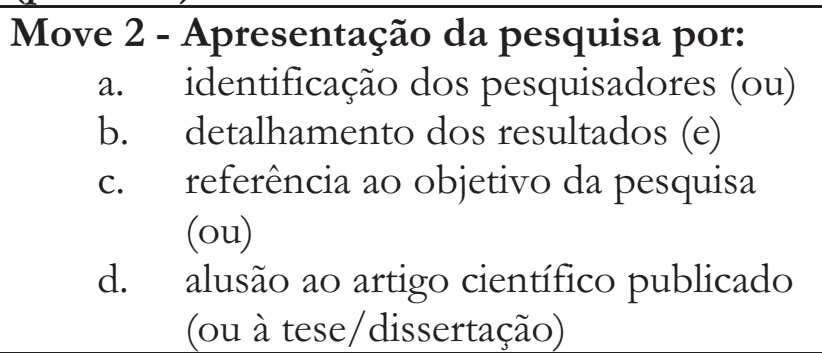 & \\
\hline $\begin{array}{l}\text { Move } 3 \text { - Referência a conhecimento } \\
\text { prévio (contextualização) por: } \\
\text { a. referência ao conhecimento } \\
\text { estabelecido na área } \\
\text { b. ênfase na perspectiva social } \\
\text { c. alusão a pesquisas prévias } \\
\text { d. indicação das limitações no } \\
\text { conhecimento estabelecido }\end{array}$ & \\
\hline $\begin{array}{l}\text { Move } 4 \text { - Descrição da metodologia por: } \\
\begin{aligned} \text { a. } & \text { identificação do procedimento } \\
& \text { experimental } \\
\text { b. } & \text { referência aos dados (fonte, } \\
& \text { amplitude, data, local, categoria) }\end{aligned}\end{array}$ & \\
\hline $\begin{array}{l}\text { Move } 5 \text { - Explicação dos resultados da } \\
\text { pesquisa por: } \\
\text { a. exposição dos resultados } \\
\text { b. comparação das pesquisas atuais e } \\
\text { anteriores quanto a/à: } \\
\text { (1) conhecimento estabelecido } \\
(2) \text { metodologia utilizada } \\
\text { (3) resultados obtidos }\end{array}$ & \\
\hline $\begin{array}{l}\text { Move } 6 \text { - Indicação de conclusões da } \\
\text { pesquisa por: } \\
\text { a. menção a implicações da pesquisa } \\
\text { b. sugestão de futuras pesquisas } \\
\text { c. ênfase na perspectiva local } \\
\text { d. indicação das limitações da pesquisa } \\
\text { popularizada }\end{array}$ & \\
\hline
\end{tabular}

Quadro 4 - Representação esquemática da organização retórica de notícias de popularização da ciência. 
'Elemento' é definido aqui, conforme Hasan (1989, p.56), como um estágio textual, um trecho com alguma consequência para a progressão do texto. Esses elementos recorrentes dizem respeito ao fenômeno da alternância de vozes de diferentes atores sociais e ao caráter pedagógico das notícias de PC para explicação de princípios e conceitos.

Nossa descrição guarda semelhanças com a estrutura textual da "matéria de divulgação científica" descrita por Gomes (2000, p. 104), com título, abertura, contextualização, metodologia, perspectivas e ponto de vista. ${ }^{4}$

Em relação à alternância de vozes, notícias de PC publicadas em mídia de massa são construídas a partir de diferentes pontos de vista, alçadas pelo jornalista ao plano frontal do texto, de forma a permitir o engajamento dos sujeitos no discurso científico, como interlocutores de importância simétrica (analogamente à polifonia dos personagens relatada por Bakhtin, ao sugerir um "mundo de sujeitos investidos de plenos direitos", numa "interação de consciências plenivalentes", que aceita uma "multiplicidade de posições ideológicas equicompetentes" (2008, p. 5-7, 19).

Essa dinâmica polifônica se realiza por meio da análise da descoberta científica sob vários pontos de vista (BEACCO et al., 2002), com diferentes segmentos da sociedade opinando sobre a validade da pesquisa. Assim, conforme argumentamos em trabalhos anteriores (MARCUZZO; MOTTA-ROTH, 2008; MOTTA-ROTH et al., 2008a), na notícia de PC, além da voz do jornalista-autor, obviamente presente no texto, o elemento da alternância de vozes legitima diferentes opiniões sobre a pesquisa científica (que podem ser do pesquisador, de colegas pesquisadores, do público, etc.).

A alternância de vozes semelhante à polifonia se constitui em um confronto de ideias, expressa opiniões de diferentes atores sociais em oposição ou alinhamento. A alternância de vozes, por seu dialogismo, inscreve a notícia de PC como um gênero com uma dinâmica discursiva

\footnotetext{
${ }^{4}$ Gomes (2000, p. 104) sugere que o título (título propriamente dito e o subtítulo) tem como função resumir a informação desenvolvida no corpo do texto; a abertura contém dados que situam o estudo; a contextualização informa o objeto de estudo da pesquisa ou o contexto em que se insere; a metodologia explica os materiais ou métodos utilizados; as perspectivas abordam os horizontes da pesquisa; finalmente, o ponto de vista indica, explícita ou implicitamente, a opinião do autor.
} 
de "compreensão" (BAKHTIN, 1992, p. 338), o jornalista vai inserindo vozes de diferentes atores sociais como para construir um raciocínio sobre os pontos mais e menos positivos da pesquisa que está sendo popularizada.

\section{Exemplo 1}

CH\#12 [Voz do pesquisador autor do estudo] "Não queríamos escolher pontos específicos da cidade para fazer a coleta porque [...]", diz o microbiologista João Carlos Tórtora, coordenador da pesquisa.

BBC\#1 [Voz de instituições] The National Childbirth Trust [...] says the study should have looked at the number of babies who $[\ldots]$.

Para Jobim e Souza (1997, p. 334-5), o diálogo entre as vozes do autor e de outros, citados por ele, confronta opiniões numa prática polifônica que expressa ideias e palavras que são, ao mesmo tempo, "alheias e próprias", e "convida o público a participar do debate". Por meio da citação, estabelece-se "o diálogo entre textos, compromisso em fazer convergir e divergir ideias próximas e distantes" (1997, p. 335).

Para Bakhtin (1992, p. 392-393), o fenômeno da polifonia sinaliza um diálogo inacabável e infinito, numa luta entre opiniões e ideologias sobre questões que não são solucionáveis no âmbito de uma época. Analogamente a essa visão, a alternância de vozes, nos nossos dois subcorpora, ocorre como um processo de alternância de pontos de vista que possibilita a expressão de ideias/opiniões de diferentes atores sociais, seja em relação de oposição seja em relação de concordância, de modo a formular avaliações sobre as pesquisas recentes relatadas em textos que popularizam a ciência na mídia de massa.

Localizada nas últimas porções do texto, a alternância de opiniões de diferentes atores sociais, por meio de comentários que expressam pontos de vista, tem a função de apresentar as conclusões da pesquisa (NWOGU, 1991, p. 118). Para nós, entretanto, é um elemento iterativo, pois o diálogo ocorre recorrentemente ao longo de todo o texto.

O caráter pedagógico das notícias de PC, por sua vez, se dá por sua capacidade de se autoexplicar (LEIBRUDER, 2000), caracterizada pela constante preocupação do jornalista em inserir explicações sobre 
princípios e conceitos científicos que estão pressupostamente fora do âmbito de conhecimento da audiência-alvo de notícias de PC. Essas explanações assumem a forma de elaborações semânticas de temos e/ou ideias, tais como os trechos sublinhados no Exemplo 2:

\section{Exemplo 2}

CH\#1 Um dos medicamentos mais disseminados pelo planeta, o ácido acetilsalićlico, conhecido popularmente como aspirina, pode ajudar no tratamento da doença de Chagas.

BBC\#1 They were broken down into three sub-sections: planned home births, unplanned home births - when a mother intended to go to hospital but was caught unawares, and a "transferred group" - when women who had planned a homebirth ended up giving birth in hospital.

No modelo de Nwogu, essas elaborações semânticas (Explicar princípios e conceitos) também são recorrentes, aparecendo no Movimento 1 (Apresentar informação prévia) e no Movimento 8 (Explicar resultados da pesquisa) como os Passos $1 \mathrm{~d}$ e $1 \mathrm{~b}$, respectivamente. Por razão de espaço, não nos deteremos aqui na discussão sobre esses dois elementos recursivos, assunto a ser tratado em trabalhos posteriores.

\section{Movimento 1}

Semelhantemente ao modelo de Nwogu (1991, p. 120-121), nossa atual representação se inicia pelo lide da notícia (Movimento 1), que serve para fornecer uma síntese prévia do tópico do discurso que, no contexto da pesquisa sendo popularizada, pode ser vista como uma verdade perene (sublinhado no Exemplo 3).

No nosso corpus, essa verdade aparece como discurso relatado por um processo verbal no presente do indicativo, sem especificação temporal, associado ao cientista responsável pela pesquisa ou por uma metonímia deste na palavra "estudo", "pesquisa", "trabalho" (o estudo/a parte representa o pesquisador/o todo) (em negrito):

Exemplo 3 
CH\#2 [Movimento 1] Estudo traça perfil do vírus no país e mostra sua adaptação aos medicamentos.

BBC\#2 [Movimento 1] HIV can survive the apparently effective onslaught of antiviral drugs for years by hiding away in the body's cells, research $\underline{\text { shows. }}$

Para Nwogu (1991), o lide ressalta o problema de pesquisa e incorpora informações que relacionam o tópico do discurso a problemas no contexto dos leitores-alvo da revista ou do jornal em questão (especialmente se a pesquisa tiver sido conduzida em um país estrangeiro). Ao localizar a informação em um contexto mais próximo do leitor, uma notícia publicada pela $B B C$ News traz no seu lide um adjunto adverbial como "In Britain, around 15,000 couples are affected by the $[. .]$.$" .$

No nosso corpus, entretanto, essa tendência não se confirmou. Em notícias de PC, o lide, mais do que apresentar e localizar o problema, parece dar uma conclusão geral da pesquisa e captar a atenção do leitor para despertar seu interesse. Funciona como um enunciado que prevê o que será tratado no(s) parágrafo(s) seguinte(s). Nesse sentido, não fornece detalhamento dos dados ou das razões para os resultados. No Exemplo 4, os lides sugerem perguntas como "O corpo reage a que vírus?" ou "Como sementes podem durar 10 anos no solo antes de germinar?"

\section{Exemplo 4}

CH\#3 [Movimento 1] Reação do corpo contra vírus prejudica o combate a bactérias

BBC\#3 [Movimento 1] Seeds of some genetically modified crops can endure in soil for at least 10 years, scientists have discovered

Para Nwogu (1991, p.120), essa função de condensar os principais resultados viria apenas no segundo movimento retórico do texto, ao qual chama de "Destacar os principais resultados da pesquisa". Concordamos com Nwogu que, sem condensar informações centrais no lide, o jornalista arrisca perder o interesse do leitor para outras notícias e matérias. No entanto, nossos textos parecem mais econômicos, pois condensam os resultados já nas primeiras linhas de abertura do texto, enquanto que, no corpus de Nwogu, os principais resultados só aparecem 
mais adiante no Movimento 2. As razões devem estar no fato de que 20 anos separam as duas pesquisas e cada vez mais cresce a premência pela informação rápida e econômica, fazendo com que os textos sejam mais enxutos e, portanto, imediatos na entrega de conteúdo central ao leitor. De fato, essa concentração nos principais resultados ainda avança para as primeiras linhas após o lide.

\section{Movimento 2}

No nosso corpus, o Movimento 2 tem a função de explicar o lide e detalhar as informações contidas nele, mais especificamente, os resultados da pesquisa que está sendo popularizada na notícia de PC. Nesse sentido, os Movimentos 1 e 2 parecem estar numa relação coesiva do tipo "previsão-detalhe" explicitada por Hoey (1983, p.138-143) em termos de relações entre orações ${ }^{5}$ ou relações oracionais. Enquanto "oração de previsão" (preview statement) (p.70), o Movimento 1 pressupõe e se completa na simplificação ou nos detalhes que serão dados pelos enunciados seguintes. A "oração de previsão" pressupõe a reação do leitor: "Dê-me mais detalhes sobre isso" ou "E qual o significado disso?”. O Passo 2b - Detalhamento dos resultados está numa relação de previsão-detalhe com a síntese do lide (ver Quadro 4).

O Exemplo 5 ilustra como o lide ("causou degeneração de células produtoras de espermatozoides”) é simplificado no primeiro parágrafo da notícia ("pode reduzir a fertilidade").

Exemplo 5

LIDE [Movimento 1] Uso da droga causou degeneração de células produtoras de espermatozoides em camundongos.

$\$ 1$ [Movimento 2] Fumar crack pode reduzir a fertilidade, aponta estudo da Universidade de São Paulo (USP)

\footnotetext{
${ }^{5}$ Hoey (1983, p. 16; 33) chama a atenção para o modo como a superfície textual fornece pistas suficientes para o leitor/ouvinte perceber com acuidade a organização da informação. Essas pistas são dadas pelas relações semânticas que se estabelecem entre as sentenças por meio dos significados lexicais, das conjunções coordenadas e subordinadas e pela repetição lexical. "A relação entre orações é o processo cognitivo por meio do qual interpretamos o sentido de uma frase ou conjunto de frases à luz da frase ou do conjunto de frases circundantes" (WINTER, 1971 apud HOEY, 1983, p. 18).
} 
Como na representação de Nwogu (1991), o Movimento 2 funciona como resposta à curiosidade despertada pelo lide. Fornece informação detalhada sobre um resultado central pontual e indica dados específicos observados no processo de pesquisa, como data, local, período de tempo, etc. em que o estudo acontece. Inclui quatro passos: (2a) identificação do(s) pesquisador(es) (em negrito) em combinação com (2b) apresentação de algum resultado ou dado específico da pesquisa (muitas vezes numérico) (sublinhado no Exemplo 6), e (2c) objetivo da pesquisa (em itálico), ou (2d) citação do artigo que deu origem à notícia de PC (em negrito e itálico).

\section{Exemplo 6}

CH\#5 [Movimento 1] Material genético de tripanossomo foi identificado em coelhos, aves e humanos

[Movimento 2] (2a) Pesquisadores brasileiros (2b) constataram que o material genético do parasita causador da doença de Chagas pode ser transferido para o genoma do hospedeiro. Os cientistas também descobriram que esse DNA do animal infectado integrado ao do Trypanosoma cruzi pode ser transmitido hereditariamente, ao menos em galinhas. $\mathrm{O}$ estudo, (2d) publicado em 23 de julho na revista Cell, sugere ainda que o mesmo mecanismo também funciona em pacientes humanos.

BBC\#7 [Movimento 1] A single gene can keep in check the tendency to pile on fat, scientists have shown.

[Movimento 2] (2a) The University of Texas team (2b) manipulated the gene, called adipose, (2c) to alter the amount of fat tissue laid down by fruit flies, worms and mice. (...) (2d) The study is published in the journal Cell Metabolism.

Os pesquisadores são comumente sinalizados pelo emprego de lexemas explícitos relativos a nacionalidade (pesquisadores brasileiros) ou menos frequentemente ao nome próprio do/a pesquisador/a, suas credenciais (Doutor, Coordenador, etc.), a instituição de origem (The University of Texas team) ou o nome do projeto de pesquisa (Bright project). Os expoentes linguísticos dos resultados geralmente são verbos relativos à atividade de pesquisa (manipulated), descoberta (descobriram, constataram) ou hipótese (may have been), associados a elementos da metodologia (manipulated the gene called adipose), em combinação com 
um sintagma preposicionado, que indica propósito (to alter). A publicação é indicada pelo seu título e geralmente por um lexema explícito como "publicado" (The study is published in the journal Cell Metabolism). Além de artigos científicos publicados em revistas especializadas, as notícias em português também popularizam teses e dissertações.

\section{Exemplo 7}

CH\#10 [...] afirma o médico Júlio Cezar Zorzetto, que desenvolveu o estudo em sua tese de doutorado na Faculdade de Medicina da USP.

No corpus, essa porção inicial frequentemente antecipa algumas informações sobre a metodologia do estudo (a espécie de dados analisados e os procedimentos experimentais implementados), adiantando detalhes da metodologia que consistentemente vai aparecer mais adiante no texto (como Movimento 4).

\section{Exemplo 8}

CH\#3 (2b) Uma equipe de pesquisadores suíços [(2a) descobriu que a resposta do sistema imune do organismo às infecções provocadas por vírus torna o ambiente corporal mais propício à proliferação de superinfecções bacterianas]. [...] (2d) Esses resultados, publicados na revista Proceedings of the National Academy of Sciences deste mês, [(4a) foram obtidos por meio de experimentos com camundongos. (4b) Submetidos à infecção com o vírus da coriomeningite linfocítica (doença que provoca sintomas semelhantes aos da gripe em roedores), os camundongos foram então infectados pela bactéria Listeria monocytogenes]. 6

BBC\#4 (2a) The Bright project [(4a) looked at (4b) varieties of sugar beet and winter oil-seed rape (4a) which had been engineered to make them tolerant of $(4 \mathrm{~b})$ specific herbicides.

(4b) The novel crops (4a) were compared (4b) with non-GM cereals (4a) grown in rotation.]

\footnotetext{
${ }^{6}$ Movimentos que ocorrem deslocados de sua ordem comum, encaixados em outros movimentos, foram demarcados com colchetes.
} 
(2b) The project concluded that the GM varieties, used in this way, did not deplete the soil of weed seeds needed by many birds and other wildlife.

Em um dos textos (CH\#3), o movimento de explicação da metodologia aplicada ao estudo (Movimento 4) aparece somente nessa síntese inicial e não no meio do texto, como de costume. Essa restrição da metodologia parece ser característica desse gênero de popularização que atende ao público leigo, diferentemente do artigo acadêmico que, por exemplo, nas áreas da saúde, tem uma metodologia bem detalhada para um público de especialistas que, muitas vezes, adotarão esses procedimentos em novas pesquisas.

\section{Movimento 3}

Em correspondência com os Movimentos 1 e 3 da descrição de Nwogu (1991, p. 117), o Movimento 3 fornece informações para que o leitor contextualize a pesquisa por ressaltar (3a) o conhecimento já estabelecido e (3b) as implicações mais amplas que extrapolam os limites da pesquisa em termos sociais, econômicos ou culturais, ou (3c) aludir à pesquisa prévia e (3d) apontar as lacunas deixadas por ela no conhecimento, em termos de debate inconcluso e falta de consenso.

O conhecimento já estabelecido é comumente descrito como uma generalização com valor de verdade (presente do indicativo, sem restrições de tempo ou lugar). No discurso científico, generalizações dessa natureza funcionam como informação prévia para o leitor (NWOGU, 1990, p. 140).

\section{Exemplo 9}

CH\#9 [Movimento 3] (3a) Os casos de dengue do tipo 2, assim como os do tipo 1, $\underline{\text { são }}$ os mais comuns no Brasil, enquanto as primeiras manifestações da dengue do tipo 3 surgiram no final dos anos 1990. O tipo 4 não é identificado no país desde o final da década 1980.

BBC\#10 [Movimento 3] (3a) Alzheimer's disease is thought to be caused by the build up of deposits of a protein in the brain. 
A ênfase na perspectiva social é feita por alusão a segmentos da sociedade externos à pesquisa que podem ser afetados ou ter relação com ela.

\section{Exemplo 10}

CH\#7 [Movimento 3] (3b) Nos últimos anos, a Organização Mundial de Saúde (OMS) vem demonstrando crescente preocupação com a venda e o uso indiscriminado de drogas nos países em desenvolvimento.

Em uma notícia que relata um estudo sobre embriaguez na adolescência, são mencionados problemas sociais de uma região na Inglaterra, local onde a pesquisa foi realizada.

\section{Exemplo 11}

BBC\#14 [Movimento 3] (3b) Recent high-profile murders in the region were carried out by teenagers who had been drinking heavily.

Alusão à pesquisa prévia pode ser feita por referência ao conhecimento gerado no passado, marcado por advérbios ou adjetivos temporais ("anteriormente", "prévios"), por um estudo ou por referência à crença de cientistas (em oposição a leigos) sobre determinada questão.

Exemplo 12

CH\#2 [Movimento 3] (3c) Os cientistas acompanham a evolução da epidemia desde 1995 na cidade de Santos (litoral de São Paulo) -- município com grande incidência de Aids e primeiro no país a adotar as drogas para o tratamento da doença.

Léxico de sentido negativo indica lacunas ou ressalvas ao conhecimento estabelecido (SWALES, 1990; NWOGU, 1991); por exemplo, conjunções adversativas ("entretanto"), lexemas explícitos avaliativos ("falha").

\section{Exemplo 13}

BBC\#8 [Movimento 3] (3a) Currently, doctors gauge fatness with a calculation of body mass index (BMI). (3d) But BMI is flawed people with lots of muscle are considered overweight. 


\section{Movimento 4}

Nossa descrição do Movimento 4 compreende os Movimentos 6 e 7 do modelo anterior. O relato da metodologia, semelhantemente ao artigo científico (NWOGU, 1991, p. 117), contém detalhes sobre (4a) procedimentos adotados no estudo reportado, bem como sobre (4b) características do corpus da pesquisa (fonte, amplitude, data, local, categoria). Verificamos o uso recorrente de verbos (de experimento) na vOz passiva e no pretérito para informar sobre os procedimentos de experimento (SWALES, 1990).

Exemplo 14

CH\#12 [Movimento 4] (4a) Os cientistas avaliaram (4b) notas que estavam em circulação no município do Rio de Janeiro e chegavam ao acaso às suas mãos [...]. (4a) Para calcular a quantidade de microrganismos, a equipe colocou as notas em uma superfície esterilizada, passou [(4b) cotonete contendo soro fisiológico esterilizado)] e depositou [(4b) o material coletado em um tubo de ensaio].

BBC\#9 [Movimento 4] (4a) Post-mortem examinations were done on (4b) 12 patients who took part in UK trials of the drugs - donepezil, rivastigmine, tacrine and galantamine.

(2a) Professor Clive Ballard, director of research at the Alzheimer's Society, and colleagues (4a) measured the concentrations of two proteins associated with the build up of plaques found in the brains with people with dementia.

(4a) The results were compared with (4b) 12 patients studied before cholinesterase drugs were available

Para Nwogu (1991, p. 120-121), ao apresentar informações nessa ordem, os resultados principais da pesquisa antes dos procedimentos metodológicos, o jornalista demonstra consciência da necessidade de sempre projetar dentro do texto aquela informação que garantirá que o interesse do leitor se mantenha ao longo da leitura do texto. No nosso corpus, informações sintéticas sobre a metodologia frequentemente aparecem deslocadas, já no segundo parágrafo, ao serem informados os principais resultados (Movimento 2). 
Tabelas e figuras estatísticas para os dados também são recorrentes na metodologia (SWALES, 1990). No entanto, no subcorpus em português, há apenas duas ocorrências de tabelas, uma para ilustrar os resultados (CH\#6) e outra para ilustrar o procedimento de experimento (CH\#7) (a título de exemplo ver Anexo 2).

Ilustrações técnico-científicas são praticamente inexistentes nos textos em inglês (BBC\#8 mostra uma imagem escaneada das camadas de gordura do corpo humano). Comumente aparecem fotos generalistas, nada técnicas, de temas ilustrativos, que não vêm diretamente da pesquisa. Dois textos do subcorpus em inglês, inclusive, mostram a mesma foto generalista, apesar de os dois estudos reportados não terem relação (um foi feito na França e outro na Inglaterra). Isso sugere um alto nível de recontextualização da pesquisa original no gênero notícia de PC, com ampla interferência do jornalista.

\section{Movimento 5}

O Movimento 5 se concentra na explicação dos resultados principais da pesquisa (NWOGU, 1991, p. 118-119); são informações relativas (5a) à exposição dos resultados propriamente ditos, (5b) à explicação destes e/ou (5c) a comparações de resultados entre a nova pesquisa e as pesquisas prévias. Para dar conta das diferentes formas da comparação entre a nova pesquisa e a prévia, acrescentamos subpassos ao Passo c, de modo a especificar quando a comparação é feita por alusão ao $(5 \mathrm{c} 1)$ conhecimento estabelecido, $(5 \mathrm{c} 2)$ à metodologia ou $(5 \mathrm{c} 3)$ aos resultados, conforme expoentes destacados em negrito, no exemplo 15.

Exemplo 15

BBC\#14 [Movimento 5] (5a) More than a third of the teenagers questioned admitted buying their own alcohol described as an "ongoing challenge" for trading standards officers.

$\mathrm{CH} \# 3$ (5b) Isso pode explicar por que doenças provocadas por bactérias são agravadas em pessoas que adquirem infecções virais. 
BBC\#7 (5c1) The adipose gene was discovered in fat fruit flies more than 50 years ago, but scientists had not pinned down its exact role.

BBC\#2(5c2) However, the NCI team used highly sensitive equipment to measure infection levels below this threshold.

CH\#6 (5c3) O resultado é similar ao de outros estudos realizados em diferentes contextos históricos, geográficos e sociais.

BBC\#14 indica um resultado específico observado na pesquisa. $\mathrm{CH \# 3}$ interpreta, na perspectiva da pesquisa, o significado de um resultado específico. Em BBC\#7, a comparação é feita pela referência ao conhecimento estabelecido na área, enquanto que, em $\mathrm{BBC \# 2,} \mathrm{a}$ comparação é feita pela menção ao método de experimento. CH\#6 ilustra a explicação dos resultados da pesquisa pela comparação de resultados da pesquisa atual com os resultados de pesquisas anteriores.

\section{Movimento 6}

Localizado nas últimas porções do texto com a função de indicar as conclusões da pesquisa, esse movimento se cumpre por meio da (6a) menção de implicações (o que o estudo indica), (6b) sugestão de pesquisas futuras, demarcando temporalmente (pretendemos, hope to, will) essa expectativa. Esse movimento também pode ser sinalizado por informações que (6c) enfatizam a perspectiva local, isto é, situam a pesquisa em uma comunidade e informam o leitor sobre o significado do problema investigado para uma determinada comunidade ou sobre as consequências da pesquisa para um dado segmento da sociedade. Por fim, também pode ser efetivado pela (6d) alusão às limitações da pesquisa reportada.

\section{Exemplo 16}

CH\#10 (Movimento 6) (6a) Segundo ele, os resultados sugerem que a redução do potencial de fertilidade deve atingir diretamente os pré-adolescentes usuários da droga, que estão em pleno processo de maturação sexual. (6b) "Pretendemos continuar essa linha de pesquisa e investigar novas drogas, como o ecstasy", completa. 
BBC\#1 (6d) However, the authors conceded that the actual data about transfers was taken from a multitude of studies and was inevitably inconsistent.

(...)(6c) Childbirth in the UK, experts stress, remains very safe.

Em CH\#10, a conclusão do estudo é sugerida por suas implicações e interpretações dos resultados e pela expectativa de pesquisas futuras. BBC\#1 ilustra a conclusão do estudo por meio da alusão a suas limitações e pela ênfase no local de abrangência do estudo.

\section{CONSIDERAÇÕES FINAIS}

Este estudo buscou verificar a existência de um padrão de organização das informações em textos extraídos de contextos de publicação semelhantes, identificados como exemplares da mesma prática discursiva situada: o gênero "notícia de PC". Conforme Hendges (2008, p.103):

Esse padrão organizacional é formado por um conjunto de componentes funcionais, interligados, mas, ao mesmo tempo, auto-suficientes, ordenados com maior ou menor rigor, os quais organizam as informações de um gênero em um todo coerente e, somados, materializam a forma e, principalmente, contribuem para a materialização da função (propósito comunicativo) do gênero.

A análise da organização retórica do gênero notícia de PC em português e em inglês indicou que esse gênero comumente traz informações relativas à síntese dos resultados (Movimento 1) no lide, seguida pela apresentação da pesquisa (Movimento 2), geralmente ou por detalhamento do lide, alusão ao autor e/ou descrição da metodologia, acompanhada por uma contextualização do estudo (Movimento 3). $\mathrm{Na}$ sequência, são detalhados os dados e os procedimentos metodológicos adotados (Movimento 4). Os últimos dois estágios textuais explicam os resultados (Movimento 5) e as conclusões da pesquisa (Movimento 6). Perpassando todo o texto, há comentários que expressam pontos de vista que avaliam a pesquisa (Elemento A), e explicações de princípios e 
conceitos (Elemento B), quando o jornalista julga necessário explicar termos e/ou ideias para facilitar a leitura do conteúdo científico da notícia.

Dentre as diferenças entre os dois subcorpora, notamos que as notícias em português fazem, no trecho inicial de contextualização, pouco contraste com pesquisas prévias relacionadas ao estudo sendo popularizado (Movimento 3 - Passos c e d), diferentemente das notícias em inglês. Como esse contraste é comum no início de artigos científicos para abrir um nicho e ressaltar o ineditismo da nova pesquisa (SWALES, 1990), sua posição inicial sugere uma maior semelhança das notícias em inglês com o artigo científico. Em português, esse contraste com pesquisas anteriores aparece comumente ao final, na explicação dos resultados (Cf. CH\#9 \$6, CH\#6\3, CH\#13\$3, CH\#8 \$6). Outra diferença diz respeito ao fato de que as notícias em inglês comumente popularizam pesquisas que foram publicadas na forma de artigos científicos, enquanto que, em português, é comum noticiar-se uma pesquisa fazendo referência à tese de doutorado ou dissertação que a originou. Essa parece ser uma evidência de maior visibilidade e valorização, no contexto britânico, de pesquisas publicadas em revistas científicas em comparação ao contexto brasileiro. Apesar dessas diferenças, a representação esquemática do gênero notícia de PC apresentada neste trabalho, de modo geral, parece captar a forma como esses textos se organizam retoricamente nas duas línguas. $O$ levantamento da ocorrência dos movimentos indicou que todos eles se realizam praticamente em todos os textos analisados, com exceção da Referência a conhecimento prévio (contextualização) (Movimento 3) que aparece em $80 \%$ dos textos em português.

A análise ainda carece de refinamento em função do tamanho reduzido do corpus. Para alcançar um poder maior de generalização, a pesquisa já está sendo ampliada para incorporar mais 15 notícias em cada língua (30 ao todo). Quanto às diferenças entre os dois subcorpora, uma delas diz respeito ao fato de as notícias em português preservarem mais claramente a visão dominante (HILGATERNER, 1990) ou tradicional (MOIRAND, 2003) da ciência, o que confere a essas um caráter monológico, quando somente a comunidade científica tem autoridade para debater e avaliar a pesquisa. Em contraponto, as notícias em inglês apresentam um caráter contra-hegemônico, pois oferecem pontos de 
vista variados sobre o (in)sucesso da nova pesquisa, oportunizando a expressão de outros segmentos e instituições da sociedade sobre o impacto e a aplicabilidade das pesquisas científico-tecnológicas. O papel da alternância de vozes nesse gênero de PC será aprofundado em trabalho posterior.

Apesar das várias lacunas que persistem no nosso conhecimento sobre o processo de popularizar a ciência e os recursos discursivos mobilizados por esse processo social, acreditamos ter demonstrado o modo como certos aspectos do processo social de popularizar a ciência são linguisticamente realizados no gênero notícias de PC.

Evidentemente a análise é difícil, e é trabalhosa a delimitação de partes do texto como movimentos e passos regulares, pois se baseia no processo interpretativo do analista. Bonini (no prelo, p.17-18) reconhece a complexidade da análise:

Much of the texts' complexity and difficulties in genre distinction is mitigated by this focus on the texts' regularities. [...] What the data show, actually, is that the boundaries between these journalistic genres are quite blurred. [...] From this perspective, we can say that genres exist in a complex ecology of gradual distinctions.

Além disso, conforme mencionado acima, Bonini (no prelo, p. 18) aponta a dificuldade de diferenciar notícia e reportagem na mídia norteamericana, por exemplo, ressaltando que há, no mundo, diferentes "ecologias de gênero", o modo como as pessoas se adaptam em certos ambientes por meio de práticas que realizam e os gêneros que usam. Essas ecologias de gênero evidenciam as compreensões e os usos idiossincráticos de artefatos e práticas do nosso meio histórico-cultural (SPINUZZI apud BONINI, no prelo, p.18). Em nosso estudo, encontramos vários pontos comuns nos dois subcorpora em português e inglês, portanto, concordamos com Bonini ao reconhecer que diferentes ecologias de gênero provavelmente funcionem em contextos anglofônicos e lusofônicos, mas ainda não podemos concluir que gêneros e práticas são diferentes nos contextos brasileiro e estrangeiro.

Resta a necessidade de aprofundarmos o debate sobre as diferentes perspectivas presentes nas notícias em português e inglês, de modo a confirmarmos ou não "o caráter transacional da linguagem 
jornalística" (LAGE apud FRANCESCHINI, 2004, p. 149), que confere às notícias uma organização universal independente do contexto histórico-cultural de realização. A academia e a sociedade como um todo também se beneficiaria de mais pesquisas que aprofundem a reflexão e alimentem o debate sobre a ciência que se produz, os processos de reificação da pesquisa científica e sua publicação, a disseminação do letramento científico, a popularização da informação e a democratização do acesso aos bens científicos. Esses certamente são temas que demandam pesquisas futuras.

\section{REFERÊNCIAS}

AL-ALI, M. N. Religious affiliations and masculine power in Jordanian wedding invitation genre. Discourse \& society, v. 17, n. 6, p. 691-714, 2006.

ALBAGLI, S. Divulgação científica: informação cientifica para a cidadania? Ciência da informação, v. 25, n. 3, p. 396-404, 1996.

ANDRADE, P. Literacia científico-tecnológica e opinião pública no quadro da ciência lusófona e do movimento museabilidade. In: SOUSA, C. M.; PERIÇO, N. M.; SILVEIRA, T. S. (Orgs.). A comunicação pública da ciência. Taubaté, SP: Cabral Editora e Livraria Universitária, 2003. p. 95-112.

BAKHTIN, M. Estética da criação verbal. São Paulo: Martins Fontes, 1992.

Problemas da poética de Dostoiévski. Tradução de Paulo Bezerra.

4. ed. Rio de Janeiro: Forense-Universitária, 2008.

BEACCO, J-C.; CLAUDEL, C.; DOURY, M.; PETIT, G.; REBOUL-TOURÉ, $\mathrm{S}$. Science in media and social discourse: new channels of communication, new linguistic forms. Discourse studies, v. 4, n. 3, p. 277-300, 2002.

BERKENKOTTER, C. Genre systems at work: DSM-IV and rhetorical recontextualizatiom in psychotherapy paperwork. Written communication, v. 18, p. 326-49, 2001.

BHATIA, V. Worlds of written discourse: a genre-based view. London, New York: Continuum, 2004.

Analysing genre: language use in professional settings. London:

Longman, 1993.

MOTTA-ROTH; LOVATO - Organização retórica do gênero notícia de popularização... 
BOND, F. F. An introduction to journalism: a survey of the fourth estate in all its forms. $1^{\text {st }}$ ed. New York: Macmillan, 1954.

BRASIL. MEC. Secretaria da Educação Fundamental. Parâmetros

Curriculares Nacionais: introdução. Brasília: MEC, 1997a. Disponível em: <http://mecsrv04.mec.gov.br/sef/estrut2/pcn/pdf/livro01.pdf >. Acesso em: 21 fev. 2006.

. MEC. Secretaria da Educação Fundamental. Parâmetros Curriculares

Nacionais: Apresentação dos temas transversais, ética. Brasília: MEC, 1997b.

Disponível em: <http://mecsrv04.mec.gov.br/sef/estrut2/pcn/pdf/ livro081.pdf>. Acesso em: 12 mar. 2007.

. MEC. Secretaria da Educação Fundamental. Parâmetros Curriculares Nacionais: Saúde. Brasília: MEC, 1997c. Disponível em: < http://mecsrv04. mec.gov.br/sef/estrut2/pcn/pdf/livro092.pdf>. Acesso em: 12 mar. 2007.

. MEC. Secretaria da Educação Fundamental. Parâmetros Curriculares Nacionais: Meio Ambiente. Brasília: MEC, 1997d. Disponível em:

<http://mecsrv04.mec.gov.br/sef/estrut2/pcn/pdf/livro091.pdf>. Acesso em: 12 mar. 2007.

BONINI, A. The distinction between news and reportage in the Brazilian journalistic context: a matter of degree. In: BAZERMAN, C.; BONINI, A.; FIGUEIREDO, D. C. (Orgs). Genre in a changing world - advances in genre theory, analysis, and teaching. West Lafayette, IN: Parlor Press; Fort Collins, CO: WAC Clearinghouse, [no prelo].

CALDAS-COULTHARD, C. R. News as social practice: a study in critical discourse analysis. Florianópolis: Pós-graduação em Inglês, UFSC, 1997.

CALSAMIGLIA, H.; VAN DIJK, T. Popularization discourse and knowledge about the genome. Discourse \& society, v. 15, n.4, p. 369-389, 2004.

CERRATO, S. Pop-science on the Internet: how ULISSE makes the ends meet. In: INFORMING SCIENCE + IT EDUCATION CONFERENCE. Cork, Ireland. Proceedings of the... 2002. Disponível em: < http://proceedings. informingscience.org/IS2002Proceedings/papers/Cerra195Uliss.pdf $>$. Acesso em: 11 jul. 2007.

FAIRCLOUGH, N. Language and power. London: Longman, 1989.

Discourse and social change. Cambridge: Polity Press, 1992.

Analysing discourse: textual analysis for social research. London;

New York: Routledge, 2003. 
FRANCESCHINI, F. Notícia e reportagem: sutis diferenças. Comum, Rio de Janeiro, v.9, n. 22, p. 144-155, 2004. Disponível em: <http://www.facha. edu.br/publicacoes/comum/comum22/Artigo6.pdf>. Acesso em: 18 jan. 2009.

GOMES, I. M. de A. M. A divulgação científica em Ciência Hoje: características discursivo-textuais. Recife, 2000. 287f. Tese (Doutorado em Letras) - Programa de Pós-Graduação em Letras, Universidade Federal do Ceará, 2000.

HASAN, R. Part B. In: HALLIDAY, M. A. K.; Language, context, and text: aspects of language in a social-semiotic perspective. Oxford: Oxford University Press, 1989. p. 52-118.

HENDGES, G. R. Procedimentos e categorias para a análise da estrutura textual de gêneros. In: MOTTA-ROTH, D.; CABAÑAS, T.; HENDGES, G. R. (Orgs). Análises de textos e de discursos: relações entre teorias e práticas. Santa Maria, RS: PPGL Editores, 2008. p. 101-129.

HILGARTNER, S. The dominant view of popularization: conceptual problems, political uses. Social studies of science, v. 20, n. 3, p. 519-139, 1990.

HOEY, M. On the surface of discourse. London: George Allen \& Unwin, 1983.

JOBIM E SOUZA, S. Mikhail Bakhtin e Walter Benjamin: polifonia, alegoria e o conceito de verdade no discurso da ciência contemporânea. In: BRAIT, B. (Org.). Bakhtin, dialogismo e construção do sentido. 1. ed. Campinas: UNICAMP, 1997. p. 331-348.

LAGE, N. Linguagem jornalística. 7. ed. São Paulo: Ática, 2004. A estrutura da notícia. 5. ed. São Paulo: Ática, 2005.

LEIBRUDER, A. P. O discurso de divulgação científica. In: BRANDÃO, H. N. Gêneros do discurso na escola: mito, conto, cordel, discurso político, divulgação científica. São Paulo: Cortez, 2000. (Coleção Aprender e ensinar com textos, v. 5)

MARCUZZO, P.; MOTTA-ROTH, D. Polifonia e avaliação em notícias de popularização da ciência. In: CÍRCULO DE ESTUDOS LINGUÍSTICOS DO SUL (CELSUL), 8., 2008, Porto Alegre. Anais... Porto Alegre: UFRGS/CELSUL, 2008. 1 CD-ROM.

MARTIN, J.R.; ROSE, D. Genre relations: mapping culture. London: Equinox, 2007. 
MEDEIROS, R. O conhecimento socializado e o papel do jornalismo no contexto da divulgação da ciência. In: SOUSA, C. M.; PERIÇO, N. M.; SILVEIRA T. S. (Orgs.). A comunicação pública da ciência. Taubaté, SP: Cabral Editora e Livraria Universitária, 2003. p.79-93.

MOIRAND, S. Communicative and cognitive dimensions of discourse on science in the French mass media. Discourse studies, v. 5, n. 2, p. 175-206, 2003.

MOREIRA, T. M.; MOTTA-ROTH, D. Popularização da ciência: uma visão panorâmica do Diário de Santa Maria. In: CÍRCULO DE ESTUDOS LINGUÍSTICOS DO SUL (CELSUL), 8., 2008, Porto Alegre. Anais... Porto Alegre: UFRGS/CELSUL, 2008. 1 CD-ROM.

MOTTA-ROTH, D. Rhetorical features and disciplinary cultures: a genre based study of academic book reviews in linguistics, chemistry and economics. Florianópolis, 1995. 311f. Tese (Doutorado em Letras) - Programa de PósGraduação em Inglês, Universidade Federal de Santa Catarina, 1995.

Análise crítica de gêneros com foco em artigos de popularização

da ciência. Projeto de Produtividade em Pesquisa PQ/CNPq (nº 301962/20073), 2007. Disponível em <http://coralx.ufsm.br/desireemroth/ Projeto_Comite_Etica.pdf $>$ Análise crítica de gêneros: contribuições para o ensino e a pesquisa de linguagem. D.E.L.T.A., v. 24, n.2, p. 341-383, 2008.

; MARCUZZO, P.; NASCIMENTO, F. S.; SCHERER, A. S. Polifonia em notícias de popularização da ciência sob a ótica sistêmico-funcional. In: CONGRESSO INTERNACIONAL DA ASSOCIAÇÃO DE LINGUÍSTICA SISTÊMICO-FUNCIONAL DA AMÉRICA LATINA (ALSFAL), 4., 2008, Florianópolis. Resumos... Florianópolis: UFSC, 2008a.

; GERHARDT, L; LOVATO, C. Organização retórica do gênero notícia de popularização da ciência: um estudo comparativo entre português e inglês. In: CÍRCULO DE ESTUDOS LINGUÍSTICOS DO SUL (CELSUL), 8., 2008, Porto Alegre. Anais... Porto Alegre: UFRGS/CELSUL, 2008b. 1 CDROM.

MYERS.G. Writing biology: texts in the social construction of scientific knowledge. Madison: University of Wisconsin Press, 1990.

Discourse studies of scientific popularization: questioning the boundaries. Discourse studies, v. 5, n. 2, p. 265-279, 2003. 
NASCIMENTO, F. S.; SCHERER, A. S.; MOTTA-ROTH, D. O status da linguagem em publicações on-line de divulgação científica. In: SEMANA ACADËMICA DE LETRAS UFSM: A Construção da Identidade e da Brasilidade do Sujeito de Letras, 2008, Santa Maria. Resumos... Santa Maria: UFSM, 2007. p. 49.

NWOGU, K. Discourse variation in medical texts: scheme, theme and cohesion in professional and journalistic account. Monographs in systemic linguistics, Nottingham: University of Nottingham, v. 2, 1990.

Structure of science popularization: a genre analysis approach to the schema of popularized medical texts. English for specific purposes, v. 10, n. 10, p. 111-123, 1991.

OLIVEIRA, J. M. de. As vozes da ciência: a representação do discurso nos gêneros artigo acadêmico e de divulgação científica. Belo Horizonte, 2005. Tese (Doutorado em Letras) - Programa de Pós-graduação em Linguística, Universidade Federal de Minas Gerais, 2005.

; PAGANO, A. The research article and the science popularization article: a probabilistic functional grammar perspective on direct discourse representation. Discourse \& society, v. 8, n. 5, p. 627-646, 2006.

PAGANO, A. Genes, ovelhas e discos compactos: alguns aspectos das reescritas de descobertas científicas. In: MACHADO, I.; L. CRUZ, A.; LYSARDO-DIAS, D. Teorias e práticas discursivas: estudos em análise do discurso. Belo Horizonte: UFMG/Carol Borges, 1998. p. 55-72.

. Gêneros híbridos. In: MAGALHÃES, C. (Org.). Reflexões sobre a análise crítica do discurso. Belo Horizonte: Editora da UFMG, 2001. p. 83104.

PAUL, D. Spreading chaos: the role of popularizations in the diffusion of scientific ideas. Written communication, v. 21, n. 1, p. 32-68, 2004.

PRATES, N. D.; SCHERER, A. S.; MOTTA-ROTH, D. Organização retórica e uso de aposto em artigos de popularização da ciência. In: SEMINÁRIO DO GEL - GRUPO DE ESTUDOS LINGUÍSTICOS, 56. Anais... São José do Rio Preto: UNIP, 2008.

SWALES, J. Genre analysis: English in academic and research settings. Cambridge: Cambridge University Press, 1990.

Research genres: exploration and applications. Cambridge:

Cambridge University Press, 2004. 


\section{ANEXO 1}

\section{BBC\#8}

Fat scan shows up 'true' obesity

\begin{tabular}{|c|c|}
\hline Parágrafos & Movimentos e Passos \\
\hline LIDE & $\begin{array}{l}\text { (A1) Scientists say (1) they have developed a 3D scanner that } \\
\text { can accurately determine if a person is truly obese. }\end{array}$ \\
\hline$\$ 1$ & $\begin{array}{l}\text { (3a) Currently, doctors gauge fatness with a calculation of body } \\
\text { mass index (BMI). (3d) But BMI is flawed - people with lots of } \\
\text { muscle are considered overweight. }\end{array}$ \\
\hline$\$ 2$ & 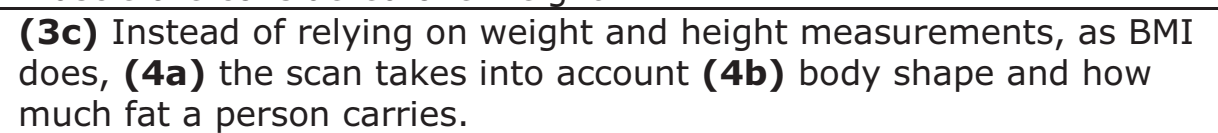 \\
\hline$\$ 3$ & $\begin{array}{l}\text { (2a) Birmingham's Heartlands Hospital (4a) has been testing this } \\
\text { Body Volume Index. }\end{array}$ \\
\hline$\$ 4$ & $\begin{array}{l}\text { Muscle or fat? } \\
\text { (4b) One human guinea pig [(4a) who has tested the BVI scanner] } \\
\text { is } 19 \text {-year-old rower Ashley Granger. }\end{array}$ \\
\hline$\S 5$ & $\begin{array}{l}\text { (4b) He is } 6 \mathrm{ft} \text { 2ins }(1.88 \mathrm{~m}) \text { tall and according to his BMI of } 28 \text { is at } \\
\text { the top end of the overweight category, borderline obese. }\end{array}$ \\
\hline$\$ 6$ & $\begin{array}{l}\text { (5a) His BVI scan correctly showed that he carries very little fat and } \\
\text { that his weight is largely down to muscle. }\end{array}$ \\
\hline \$7 & $\begin{array}{l}\text { (A2) Fitness trainer Matt Roberts said: (3a) "Muscle weighs more } \\
\text { than fat does. And you can hide away fat but be quite thin looking. }\end{array}$ \\
\hline$\$ 8$ & (A2) (3d) "So it's important that we don't just use BMI alone." \\
\hline$\$ 9$ & $\begin{array}{l}\text { [(A1) Dr Asad Rahim, a consultant in the obesity and endocrinology } \\
\text { department at Heartlands Hospital, explained] the work they had } \\
\text { done with the BVI scanner over the last two years. }\end{array}$ \\
\hline$\$ 10$ & $\begin{array}{l}\text { (A1) (5a) "We have completed the patient evaluation stage and are } \\
\text { currently assessing the results." }\end{array}$ \\
\hline$\$ 11$ & $\begin{array}{l}\text { (A1) (5a) "The scanner has certainly helped motivate some patients } \\
\text { to manage their weight more effectively }(\mathbf{6 d}) \text { but there are also } \\
\text { patients who were not scanned who lost weight." }\end{array}$ \\
\hline$\$ 12$ & $\begin{array}{l}\text { (6b) The next phase of testing has now been launched - the plan is } \\
\text { to scan at least } 20,000 \text { people over the next two years as part of the } \\
\text { Body Benchmark Study. }\end{array}$ \\
\hline$\S 13$ & $\begin{array}{l}\text { (A2) (6a) Select Research, the company which makes the scanners, } \\
\text { said it hoped to make them available to GP surgeries at an } \\
\text { "affordable" cost. }\end{array}$ \\
\hline
\end{tabular}




\section{ANEXO 2}

CH\#6

HOMENS ESTRESSADOS, DOENÇAS À VISTA?

Estresse causa mais alterações imunes e hormonais na população masculina do que na feminina

Uma recente pesquisa realizada no Instituto de Ciências [...]

A grande surpresa, no entanto, ocorreu na comparação entre os sexos. Os homens sofreram mais alterações em seu sistema imune do que as mulheres. A variação mais frequente foi a diminuição no número de células responsáveis pela resposta imune específica (forma mais eficaz e mais demorada de combate a agressões sofridas pelo organismo) e aumento nos parâmetros responsáveis pela imunidade inata, primeira forma de autodefesa do corpo, mas menos eficiente.

Segundo Faustino, as mudanças no sistema imune estão relacionadas a alterações nos níveis dos hormônios ACTH (que controla a liberação do hormônio cortisol) e noradrenalina. $O$ experimento afetou a porcentagem de células NK (responsáveis por combater vírus e células cancerosas) no sangue, o que está associado à liberação de adrenalina e noradrenalina - fortemente influenciada pelas reações emocionais dos participantes.

Os testes também interferiram nas taxas de cortisol, que tiveram um pico durante o período de estresse, independentemente do sexo ou dos grupos estudados. A maior liberação do hormônio, no entanto, ocorreu nos homens. "Mas o aumento verificado não ultrapassou os índices considerados normais, o que pode ser parcialmente explicado pelo fato dessas situações terem sido simuladas em laboratório", ressalta. 

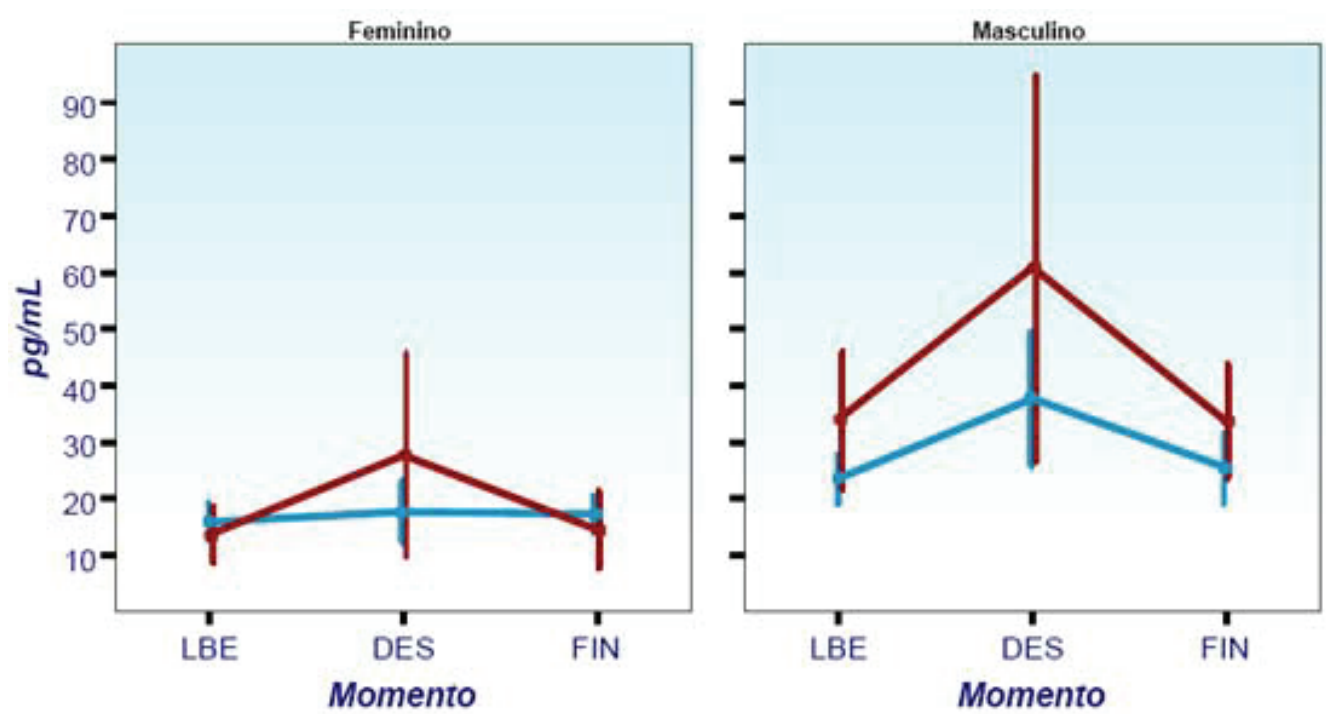

Níveis de ACTH no sangue ao longo do experimento. A maior liberação acontece nos homens e durante o discurso em frente à câmera de vídeo. Mesmo com as variações, os níveis hormonais dos grupos com fobia social (em vermelho) e sem patologia (em azul) permaneceram dentro dos limites normais da população brasileira.

$[\ldots]$

JoãoGabrielRodrigues

CiênciaHoje On-line

$17 / 04 / 2007$

Recebido em 08/10/08. Aprovado em 25/03/09.

Title: Rhetorical organization of science popularization news genre: a comparative study between Portuguese and English

Author: Désirée Motta-Roth; Cristina dos Santos Lovato

Abstract: The objective of this study is to compare the rhetorical organization of 30 popularization of science news, in Portuguese and English, from the sites Ciência Hoje On-line and BBC Online. In general, we found the indication of general results in the lead, followed by the presentation of the research by detailing of results, description of experimental procedures with the explanation of results and conclusion in the last portion of the text. We verified certain characteristics credited to the popular character of the news in the mass media, such as the lead that synthesizes the research results, 
the appelation to authority in the presentation of researchers' credentials, the short explanation of methodology, the allusion to the social and local character of the research in relation to the a given community. We noticed the recurrence of concept explanation and evaluation of research by different segments of society. This article discusses and illustrates each one of these characteristics and proposes a schematic representation of science popularization news texts.

Keywords: critical genre analysis; pop science news; rhetorical organization.

Titre: Organisation rhétorique du genre informations de popularisation de la science: une étude comparative entre le portugais et l'anglais

Auteur: Désirée Motta-Roth; Cristina dos Santos Lovato

Résumé: L'objectif de cette étude est celui de comparer l'organisation rhétorique de 30 informations de popularisation de la science, publiées en portugais et en anglais, dans les sites "Ciência Hoje On-Line" et "BBC Online". D’une manière générale, on a rencontré l'indication des résultats généraux dans les rubriques, suivie de la présentation de la recherche par détails des résultats, description des procédés expérimentaux, avec l'explication des résultats et la conclusion de la recherche dans la partie de la fin du texte. On a vérifé certaines caractéristiques, telles que les rubriques qui synthétisent les résultats de la recherche, la présentation des créances des chercheurs comme étant une ressource d'autorité, l'explication concise de la méthodologie et l'allusion au caractère social et local de la recherche par rapport à une certaine communauté. On a remarqué la récurrence de l'explication de concepts et de l'évaluation de la recherche par plusiuers segments de la société. Cet article discute et illustre chacune de ces caractéristiques et propose une représentation schématique du genre informations de popularisation de la science.

Mots-clés: analyse critique de genre; organisation rhétorique; informations de popularisation de la science.

Título: Organización retórica del género noticia de popularización de la ciencia: un estudio comparativo entre portugués e inglés

Autor: Désirée Motta-Roth; Cristina dos Santos Lovato

Resumen: El objetivo de este estudio es comparar la organización retórica de 30 noticias de popularización de la ciencia, publicadas en portugués y en inglés, en los sitios Ciencia Hoy On-line y BBC Online. De modo general, encontramos la indicación de los resultados generales en el trabajo, seguida de la presentación de la investigación por detallados de los resultados, descripción de los procedimientos experimentales, con la explicación de los resultados y la conclusión de la investigación en la parte final del texto. Verificamos ciertas características, tales como el trabajo que sintetiza los resultados de la investigación, la presentación de las credenciales de los investigadores como recurso de autoridad, la explicación sucinta de la metodología y la alusión al carácter social y local de la investigación en relación a una determinada comunidad. Notamos la recurrencia de la explicación de conceptos y de la evaluación de la investigación por diferentes segmentos de la sociedad. Este artículo discute e ilustra cada una de esas características y propone una representación esquemática del género noticia de popularización de la ciência.

MOTTA-ROTH; LOVATO - Organização retórica do gênero notícia de popularização... 
Palabras-clave: análisis crítico de género; organización retórica; noticia de popularización de la ciência. 